\title{
Dysregulation of Type II Transmembrane Serine Proteases and Ligand-Dependent Activation of MET in Urological Cancers
}

\author{
Shoichiro Mukai ${ }^{1, *}$, Koji Yamasaki ${ }^{1}$, Masato Fujii ${ }^{1}$, Takahiro Nagai ${ }^{1}$, Naoki Terada ${ }^{1}$, \\ Hiroaki Kataoka ${ }^{2}$ (D) and Toshiyuki Kamoto ${ }^{1}$ \\ 1 Department of Urology, Faculty of Medicine, University of Miyazaki, Miyazaki 889-1692, Japan; \\ koji_yamasaki@med.miyazaki-u.ac.jp (K.Y.); masato_fuji@@med.miyazaki-u.ac.jp (M.F.); \\ takahiro_nagai@med.miyazaki-u.ac.jp (T.N.); naoki_terada@med.miyazaki-u.ac.jp (N.T.); \\ tkampro@med.miyazaki-u.ac.jp (T.K.) \\ 2 Oncopathology and Regenerative Biology Section, Faculty of Medicine, University of Miyazaki, \\ Miyazaki 889-1692, Japan; mejina@med.miyazaki-u.ac.jp \\ * Correspondence: syoichiro_mukai@med.miyazaki-u.ac.jp; Tel.: +81-985-85-2968
}

Received: 16 March 2020; Accepted: 7 April 2020; Published: 11 April 2020

\begin{abstract}
Unlike in normal epithelium, dysregulated overactivation of various proteases have been reported in cancers. Degradation of pericancerous extracellular matrix leading to cancer cell invasion by matrix metalloproteases is well known evidence. On the other hand, several cell-surface proteases, including type II transmembrane serine proteases (TTSPs), also induce progression through activation of growth factors, protease activating receptors and other proteases. Hepatocyte growth factor (HGF) known as a multifunctional growth factor that upregulates cancer cell motility, invasiveness, proliferative, and anti-apoptotic activities through phosphorylation of MET (a specific receptor of HGF). HGF secreted as inactive zymogen (pro-HGF) from cancer associated stromal fibroblasts, and the proteolytic activation by several TTSPs including matriptase and hepsin is required. The activation is strictly regulated by HGF activator inhibitors (HAIs) in physiological condition. However, downregulation is frequently observed in cancers. Indeed, overactivation of MET by upregulation of matriptase and hepsin accompanied by the downregulation of HAIs in urological cancers (prostate cancer, renal cell carcinoma, and bladder cancer) are also reported, a phenomenon observed in cancer cells with malignant phenotype, and correlated with poor prognosis. In this review, we summarized current reports focusing on TTSPs, HAIs, and MET signaling axis in urological cancers.
\end{abstract}

Keywords: matriptase; hepsin; hepatocyte growth factor (HGF); MET; prostate cancer; renal cell carcinoma; bladder cancer; HGF activator inhibitor (HAI)

\section{Introduction}

The interaction between cancer cells and stromal cells in the pericellular microenvironment has been fully discussed in the literature [1,2]. On the cancer cell surface, a variety of receptors for cytokines, growth factors, and protease activating-type receptor are widely expressed. The corresponding ligands (such as cytokines and growth factors) are provided from blood cells, stromal cells, and cancer cells in various situations. Among these, several growth factors must be proteolytically activated to achieve the biological activities. Recently, the activating process has been clarified. For example, hepatocyte growth factor (HGF) is secreted as an inactive zymogen (pro-HGF) by stromal fibroblasts and converted to active mature form by proteolytic cleavage [2-4]. HGF activator (HGFA) was initially identified and considered to be the single major activator in serum [3-7]. Indeed, coagulation cascade is initiated in pericancerous lesion, and then HGFA changes to the active form by thrombin-induced proteolytic 
activation [3-7]. Subsequently, several cell-surface transmembrane-type activators, including hepsin and matriptase, were identified [8-12]. These proteases may also be candidates for major activators considering HGF behavior (the so-called sticky protein) and the functional location (MET is located on the cell membrane). In physiological condition, the activation is tightly regulated by specific cell-surface protease inhibitors such as HGFA inhibitors (HAIs). However, dysregulated overactivation of pro-HGF has been reported to aggressively induce cancer invasion and metastasis through increased phosphorylation of MET [10-12]. This review focuses on the cell-surface pro-HGF activation system in urological cancers, including prostate cancer (PC), renal cell carcinoma (RCC), and urothelial carcinoma (UC) of bladder, and summarizes its significance in the progression of cancer.

\section{HGF/MET and the Related Molecules}

\subsection{HGF and MET in Cancer}

\subsubsection{HGF/MET Signaling Axis}

MET, encoded by Met proto-oncogene located on chromosome 7q31, is a tyrosine kinase-type specific receptor of HGF, which forms disulfide-inked heterodimer consisting of an extracellular alpha chain and single-pass transmembrane beta chain [3,13-15]. As shown in Figure 1, the intracellular domain of the beta chain comprises a juxtamembrane domain and catalytic kinase domain containing an activation loop and carboxy-terminal multifunctional docking site. The juxtamembrane domain downregulates the kinase activity by phosphorylation of Ser975, while the catalytic kinase domain upregulates the activity by phosphorylation of Tyr1234 and Tyr1235. The multifunctional docking sites contain Tyr1349 and Tyr1356, which lead to downstream signaling through several intracellular adaptor proteins [3,13-16]. Increased expression of MET with worse prognosis has been reported in various cancer cells, and phosphorylation (activation) potently promotes invasion and metastasis [16-19]. Activation of HGF/MET signaling axis in cancer cells also plays a significant role in proliferation, angiogenesis, epithelial-mesenchymal transition (EMT), and drug resistance $[3,13,14]$. Activation is introduced by: 1) ligand (HGF)-dependent activation, 2) reciprocal activation by overexpression-induced MET oligomerization, 3) activating point mutation of tyrosine kinase domain, and 4) transactivation by heterodimerization with another receptor tyrosine kinase $[3,13,14]$. In the ligand-dependent activation, proteolytic activation of pro-HGF is necessary. As mentioned above, two major activating protease families were reported: 1) a serum serine protease, HGFA; and 2) type II transmembrane serine proteases (TTSPs) such as matriptase, hepsin, and transmembrane protease/serine (TMPRSS) 2 [3,10-12]. Although these pro-HGF activating proteases are tightly regulated by two transmembrane serine protease inhibitors, HAI-1 and HAI-2, downregulation of HAIs has been observed in several cancers and has been shown to induce progression $[11,12]$. 


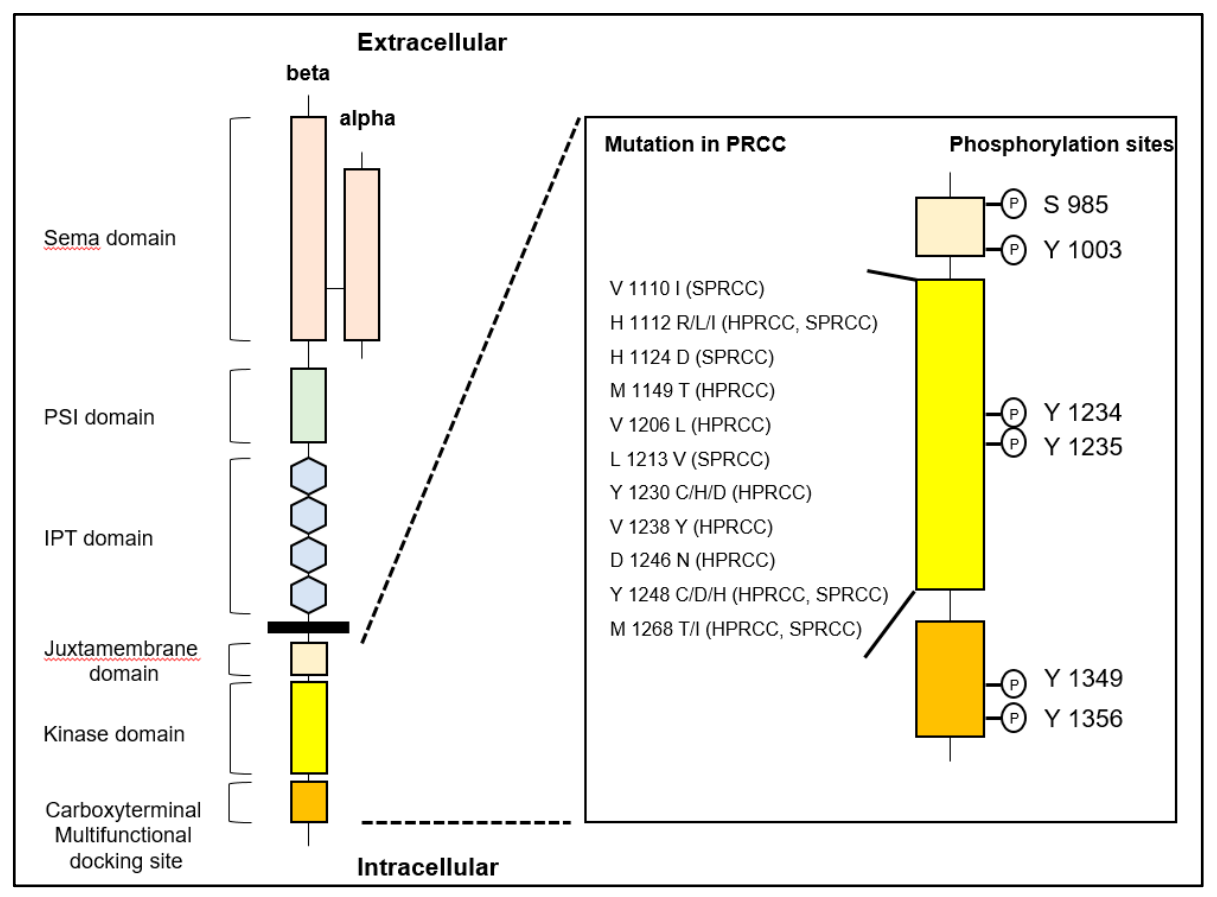

(a)



(b)

Figure 1. (a) Left: The structure of human MET is shown. MET consists of extracellular alpha and single-pass transmembrane beta chain, which are disulfide-linked heterodimer. The beta chain is composed of six major domains including Sema (semaphorin), PSI (plexin, semaphorin, integrin), IPT (immunoglobulin-like regions in plexins and transcription factors), juxtamembrane, tyrosine kinase domain, and multifunctional docking site. Right: Sites of point mutation in hereditary and sporadic papillary renal cell carcinoma (HPRCC and SPRCC) and conventional phosphorylation sites in intracellular domains are shown. (b) Left: The structure of human pro-hepatocyte growth factor (HGF) is shown. HGF consists of four Kringle domains and a serine proteinase homology domain. Right: The active form of HGF is shown. HGFA, hepsin, matriptase, and TMPRSS2 proteolytically cleave between Arg 494 and Val 495 to convert to a two-chain heterodimeric active form. One-letter abbreviation of amino acids is used. 


\subsection{Cell Surface pro-HGF Activating Enzymes and the Regulators}

\subsubsection{Type-II Transmembrane Serine Proteases (TTSP) in Cancers}

The TTSP family in humans consists of 17 serine proteases $[3,10,17]$. The structures are specified as a single-pass hydrophobic transmembrane domain near the $\mathrm{N}$-terminus with a short intracellular domain and a large extracellular portion including a carboxy-terminal serine protease domain [3,10,17]. All TTSPs are divided into the four subfamilies of hepsin, matriptase, human airway trypsin-like protease (HAT) and corin (Table 1) [3,10,17]. All TTSPs belong to the S1 peptidase family (noted in MEROPS as clan PA, family S1), and a catalytic triad consists of serine, aspartate, and histidine residues, as shown in Figure $2[20,21]$. Hepsin, matriptase and TMPRSS2 shows a strong cleavage preference for substrate with arginine in the $\mathrm{P} 1$ position [20,21]. In urogenital cancers, the expression of matriptase, hepsin and TMPRSS2 has been reported (Figure 2). Therefore, we focused on these TTSPs in this review.

Table 1. Type II transmembrane serine protease (TTSP) family content.

\begin{tabular}{cc}
\hline Subfamily & Protease \\
\hline & HAT \\
HAT/DESC & DESC1 \\
& TMPRS 11A \\
& HAT-like 4 \\
& HAT-like 5 \\
\hline Hepsin/TMPRSS & Hepsin (TMPRSS1) \\
& TMPRSS 2 \\
& TMPRSS 3 \\
& TMPRSS 4 \\
& TMPRSS 13 \\
Matriptase & Enteropeptidase \\
& Spinesin \\
\hline Corin & Matriptase \\
\hline
\end{tabular}

TTSP: type II transmembrane serine protease; HAT: human airway trypsin-like protease; DESC: differentially expressed in squamous cell carcinoma; TMPRSS: transmembrane protease, serine.

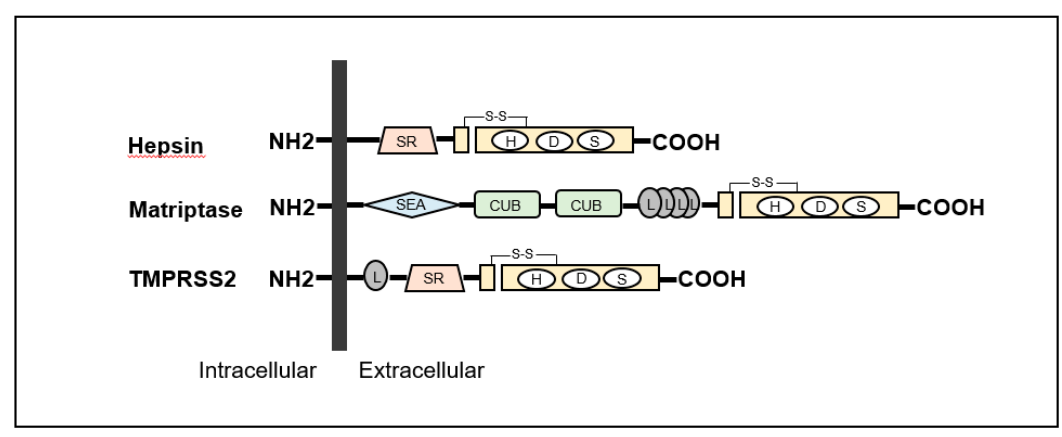

Figure 2. Structures of hepsin, matriptase and transmembrane protease serine (TMPRSS) 2 are shown. All type II transmembrane serine proteases (TTSPs) show single-pass transmembrane proteins with intracellular NH2-terminus and extracellular carboxy-terminal serine protease domains. Hepsin is composed of scavenger receptor (SR) and serine protease domains. Matriptase contains sea urchin sperm protein/enteropeptidase/agrin (SEA) domain, Cls/Cls, urchin embryonic growth factor, bone morphologic protein-1 (CUB) domain, four low-density lipoprotein receptor (L) domains class A and serine protease domains. TMPRSS2 is consists of an L domain, SR, and serine protease domains. 


\subsubsection{Matriptase}

Matriptase (MT-ST1, ST14) gene is located on human chromosome 11q24-25, and 855 amino acids are encoded in the gene $[3,10,17,18]$. The molecular weight of matriptase is $80-90-k d a$. Matriptase was first discovered in breast cancer cell line (T-47D) and purified from human milk $[3,10,17,18]$. It is expressed in human epithelial cells of various organs to maintain the formation of epithelial barrier formation [3,10-12,19]. In addition, the major enzymatic functions are reported as follows: 1) activation of hepatocyte growth factor zymogen (pro-HGF), pro-platelet-derived growth factor (PDGF)-C, -D, and pro-macrophage stimulating protein (MSP); 2) activation of protease-activated receptor (PAR)-2; 3) activation of urokinase-type plasminogen activator; 4) degradation of extracellular matrix; and 5) activation of prostasin, which is a glycosylphosphatidylinositol (GPI)-anchored protease known to activate epithelial sodium channel (ENaC) $[3,10,17,18]$. Among TTSPs, matriptase has been reported as the most efficient activator of pro-HGF [3,10-12]. HAIs are major regulators of matriptase, and deregulation of matriptase activity facilitates cancer progression [3,10-12]. Indeed, matriptase expression is reported to be upregulated in various cancers (breast, ovarian, uterine, colon, cervical, skin, pancreatic, esophageal, head and neck, prostate, bladder and renal cell carcinoma: RCC) with poor prognosis $[3,10-12,22]$.

\subsubsection{Hepsin}

Hepsin (HPN, TMPRSS1) gene is located on human chromosome 19q13.11, and 417 amino acids are encoded $[3,10,17,18]$. The molecular weight of hepsin protein is $45-\mathrm{kda}$. Although mRNA is highly expressed in liver and kidney, ubiquitous expression of the protein is reported $[3,10,23]$. The functions are reported as follows: 1) activation of pro-HGF; 2) activation of pro-MSP; 3) activation of pro-urokinase-type plasminogen activator; and 4) cleavage of laminin-332 [24]. Similar to matriptase, the catalytic activities of hepsin are regulated by HAI-1 and HAI-2 [3,10-12]. In cancer, overexpression of hepsin mRNA is reported in prostate, ovary, kidney, and breast $[3,10,17,18]$. Increased expression of the protein is also reported in prostate, ovarian, breast, and endometrial cancer $[3,10,17,18]$.

\subsubsection{Regulators of TTSPs-HAIs}

HAI-1 (SPINT-1) gene is located at 15q 15.1 and HAI-2 (SPINT-2) is located at 19q $13.2[3,11,12]$. Both proteins were initially identified in conditioned medium of human gastric cancer cell line MKN45 [3,11,12,25,26]. HAI-2 was also purified as placental bikunin from placenta $[3,11,12,27]$. The proteins have two specific extracellular Kunitz-type serine protease inhibitor domains, (KD)-1 and KD-2, except for a splicing variant of HAI-2 (isoform B has single KD) (Figure 3), which can inhibit several trypsin-like serine proteases, including all pro-HGF-activating enzymes $[3,11,12,28,29]$. Whereas, HAIs were initially discovered as HGFA inhibitors, they also inhibit matriptase and hepsin $[3,11,12]$. In addition, HAIs are required for intracellular transport and cell surface localization of matriptase in several types of cells [3,10-12]. HAI-1 is reported to express in the majority of normal epithelial cells $[3,11,12,30]$. In physiological condition, HAI-1 maintains epithelial integrity through regulation of matriptase activity $[3,11,12,30]$. HAI-1 is also required for placental differentiation, embryonic development and postnatal survival $[11,12,31]$. However, it has been reported that insufficient expression revealed dysregulation of pro-HGF activating enzymes in various cancers leading to progression [11,12]. Indeed, decreased expression of HAI-1 induced carcinogenesis (skin, intestine) and progression with worse prognosis (gastrointestinal, breast, ovarian, endometrial cancers and RCC) [11,12,32-42]. In addition, HAI-1 is also known as a suppressor of epithelial mesenchymal transition (EMT) [43]. 
HAI-1
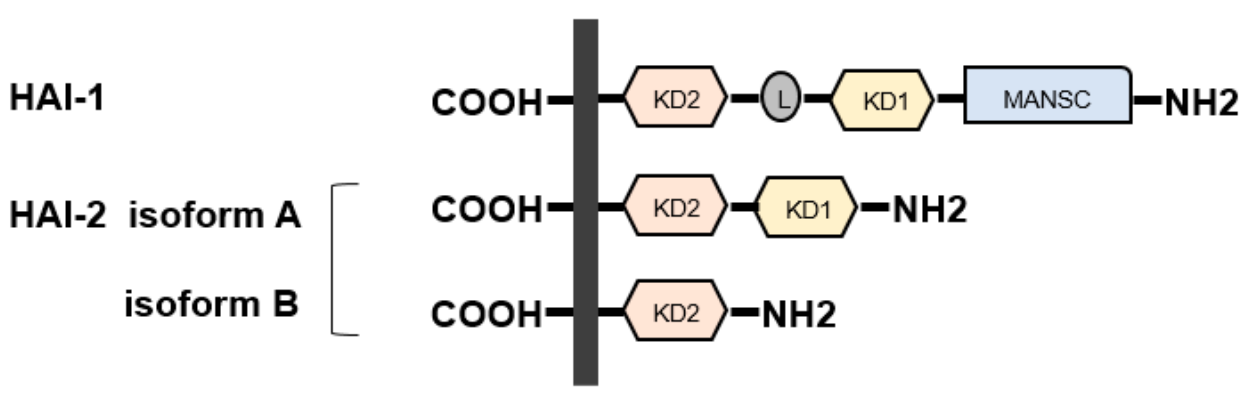

Intracellular Extracellular

Figure 3. Structures of hepatocyte growth factor activator inhibitor (HAI)-1 and HAI-2 are shown. HAIs show single-pass transmembrane protein with intracellular carboxy-terminus and extracellular specific protease inhibitor domains, the so-called Kunitz domain (KD). HAI-1 is composed of two KDs, $\mathrm{L}$ domain, and motif at $\mathrm{N}$ terminus with seven cysteines (MANSC) domains. There are two isoforms in HAI-2. Similar to HAI1, HAI-2 isoform A has two KDs, whereas isoform B has a single KD.

HAI-2 is ubiquitously expressed in normal cells, including epithelial, mesenchymal, blood cells and trophoblasts [12]. HAI-2 is reported to maintain the integrity of intestinal epithelium through regulation of matriptase-induced epithelial cell adhesion molecule (EpCAM) cleavage [44]. Downregulation by hypermethylation of SPINT2 gene has been reported in several cancers, including hepatocellular carcinoma, RCC, melanoma, gastric carcinoma, and esophageal squamous cell carcinoma [45-48]. Expression of HAI-2 is also decreased in PC. However, no apparent SPINT2 promoter methylation has been observed in either clinical samples or cell lines [49]. In this report, the authors suggest that posttranslational regulation of HAI-2 expression is essential in prostate cancer. The regulatory role of HAI-2 in the activation of pro-HGF by inhibiting the activating proteases (including matriptase), which induces HGF/MET signaling axis, has been considered a major suppressive function in cancer progression [11,12]. Additionally, an alternative function such as the activation of caspase 3 in esophageal squamous cell carcinoma leading to the promotion of apoptosis and inhibition of proliferation was also reported [47,50]. However, HAI-2 has also been reported to be required for invasive growth in oral squamous cell carcinoma, which suggests that the role of HAI-2 may be tissue or cell-type specific and dependent on targeting TTSPs [51].

\section{TTSPs and HAIs in Urological Cancers}

\subsection{Prostate Cancer}

\subsubsection{HGF/MET Signaling and Hepsin}

Increased expression of MET and phosphorylation in proliferative inflammatory atrophy (PIA) and prostatic intraepithelial neoplasia (PIN), which are known precancerous findings, have been reported [52,53]. Regarding carcinogenesis, two interesting phenomena were reported in mouse models: 1) conditional MET overexpression in prostatic luminal cells revealed development of PIN by administration of HGF, however, the conditional transgenic mouse did not produce PC [54] and 2) Conditional overexpression of hepsin in prostate epithelium revealed disruption of basement membrane in vivo [55]. These results suggested that the single expression of an HGF-related molecule may be insufficient for carcinogenesis because co-existence of MET with PTEN loss or expression of hepsin with Myc in normal prostate epithelium revealed development of cancer [54-56]. However, expression of MET in PC induced aggressive metastatic phenotype with sarcomatoid features [54], and expression of hepsin in localized cancer promoted metastatic cancer with differentiation to neuroendocrine phenotype [55]. Therefore, HGF/MET signaling and hepsin may have a significant role in the progression of PC [57-59]. Indeed, upregulation of MET was observed in metastatic lesion compared with primary site [60]. In addition, overexpression of MET is reported in patients with 
metastatic PC and positively correlated with progression [3,53,61]. Furthermore, inhibition of hepsin by small molecule inhibitor has been reported to reduce bone metastasis of PC [58].

In the normal prostate, expression of MET is observed in basal cells, but not in luminal cells [52]. Androgen receptor (AR) is, however, expressed in luminal cells [52]. Of interest, the inverse expression of MET and AR has also been reported in PC $[62,63]$. For example, MET is highly expressed in AR-negative prostate cancer cell lines such as PC3 and DU145, however, it is downregulated in AR-positive cell lines (LNCaP, LAPC-4, CWR22, and LuCaP) [62,63]. In addition, the degree of MET expression in CWR22 cell line is reported to continue increasing during the process to become androgen independent phenotype (CWR22R), and downregulation of AR induced upregulation of MET with the signaling system is observed [62,63].

Despite this, AR signaling remains in the majority of CRPC. This is explained by the clinical efficacy of AR signaling-targeted agents (abiraterone and enzalutamide) for CRPC, and a recent clinical phase III trial of cabozantinib (dual inhibitor of MET and vascular endothelial growth factor receptor for CRPC revealed insufficient results [64]. The reported efficacy of combined therapy targeting both AR and MET suggests the coexistence of AR-positive cells and MET-positive cells in CRPC [65].

\subsubsection{Matriptase and HAIs}

Inhibition of matriptase by synthetic small molecule inhibitor and analysis of downregulation using hammerhead ribozyme revealed reduced invasiveness and motility of PC cell lines [66]. The significant role of matriptase in cancers has been discussed along with the ratio of HAIs activity. Several studies revealed that overexpression and functional upregulation of matriptase rather than HAIs leads to cancer progression $[67,68]$. In PC, increased expression of matriptase with concomitant loss of HAI-1 was observed [67]. In addition, a correlation between downregulation of HAI-2 with upregulation of matriptase and increasing PC tumor grade has been reported [49,69]. However, the following evidence suggests that HAI-2 is a main regulator of matriptase [49,50,68-70]. The role of HAI-2 in invasiveness and metastatic potential of PC cells was analyzed using human prostate cancer progression model cell lines and the xenograft model $[49,68,69]$. As a result, the expression of HAI-2 but not HAI-1 in cancer cells was gradually downregulated depending on increasing invasiveness accompanying matriptase upregulation. In additional analyses, the authors confirmed that matriptase induced upregulation of PC cell motility as well as the fact that invasive and metastatic capabilities were negatively regulated by HAI-2. This phenomenon was also confirmed by the inhibition of matriptase using recombinant protein consisting of HAI-2-Kunitz domains [68,69].

\subsubsection{TMPRSS2 in PC}

As noted above, TMPRSS2 is a member of the TTSP family. In the pathogenesis of viral infection, TMPRSS2 is known to proteolytically activate spike glycoprotein of emerging coronaviruses, including severe acute respiratory syndrome (SARS) coronavirus (CoV), SARS-CoV-2 (COVID-19), human $\mathrm{CoV}-229 \mathrm{E}$, and Middle East Respiratory Syndrome CoV (CoV-EMC), which is required for virus-cell membrane fusions [71-73]. The proteolytic cleavage and activation of hemagglutinin protein are also essential for the viral infectivity of influenza A virus (strains of H1N1, H3N2, and H7N9) [73,74]. Recent studies revealed that a gene fusion of TMPRSS2 to erythroblast transformation-specific (ETS) transcription factors is commonly observed in prostate cancer tissues [75,76]. Among these, fusion of TMPRSS2 and ERG is the most common (approximately 50\%) chromosomal rearrangement [75,76]. However, no apparent proteolytic activity in this fusion protein has been reported (the protein mainly acts as a transcription factor). Expression of TMPRSS2 is positively regulated by androgens and expressed in both primary and metastatic sites of hormone sensitive PC [77,78]. Expression is reported to be increased in higher Gleason pattern $[77,78]$. As substrates, components of extracellular matrix (nidogen-1, laminin $\beta 1$ ), matriptase zymogen, and pro-HGF were reported [78]. Ko et al. reported that androgen-induced TMPRSS2 can initiate a pericellular proteolytic cascade to activate matriptase, which promotes cancer cell invasion [79]. In addition, the correlation between increased expression of 
TMPRSS2 and increased matriptase activation in PC tissue was also confirmed. They concluded that TMPRSS2 can promote PC progression through increased matriptase activation and degradation of nidogen- 1 and laminin $\beta 1$ [79].

The evidences of Sections 3.1.1-3.1.3 are summarized in Figure 4.

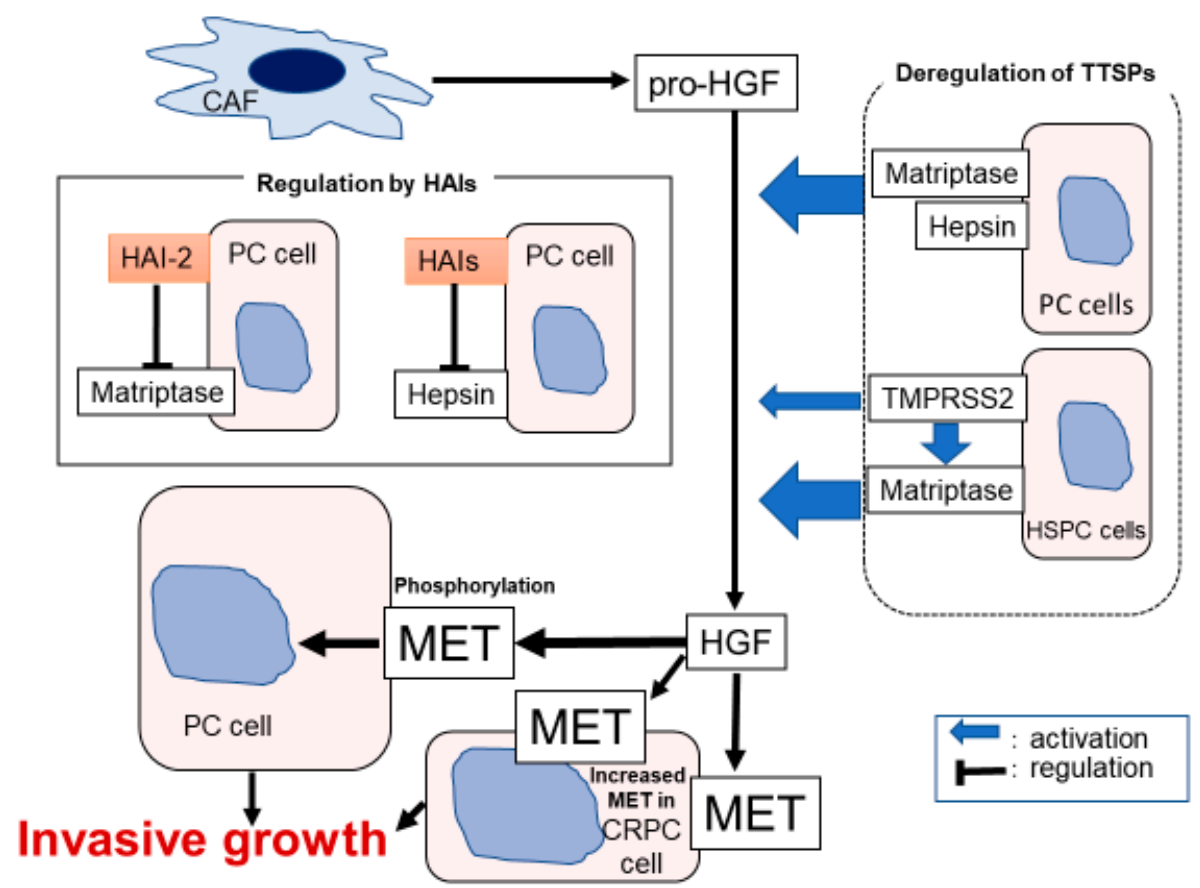

Figure 4. Hypothetical model of pericellular activation of hepatocyte growth factor zymogen (pro-HGF) in prostate cancer (PC) is shown. Downregulation of HAIs induced dysregulated overactivation of matriptase, hepsin, and TMPRSS2, leading to HGF-dependent phosphorylation of MET.

\subsection{Renal Cell Carcinoma}

\subsubsection{HGF/MET Signaling}

The most common histological subtype is clear cell RCC (approximately $80 \%-90 \%$ of RCC), followed by papillary RCC $(10 \%-15 \%)$ [80]. Since expression of MET is observed in all subtypes, activating germline point mutations of MET are well known as the major cause of hereditary papillary RCC (PRCC) type-1 $[15,16]$. The mutation occurs at the tyrosine kinase (TK) domain and induces continuous ligand-independent phosphorylation of MET $[15,16]$. Although the mutation is observed only in $10 \%-46 \%$ of sporadic PRCC, overexpression including amplification of MET is common [81]. Of interest, phosphorylation of MET with auto-activating mutation was enhanced to a significant degree by HGF stimulation [82].

Inactivation of von Hippel-Lindau (VHL) tumor suppressor gene is the most common genetic abnormality of clear cell RCC $[83,84]$. Inactivation occurs not only in VHL patients (germline mutation) but also in patients with sporadic clear cell RCC (somatic abnormality) by deletion, mutation and epigenetic hypermethylation $[83,84]$. Deficiency of VHL protein in clear cell RCC causes progression of angiogenesis through activation of hypoxia inducible factor (HIF) $1 \alpha$ and $2 \alpha$, which are major transcription factors of vascular endothelial growth factor (VEGF) and platelet-derived growth factor (PDGF) [83]. Of interest, HIF-1 $\alpha$ is also reported to activate transcription of MET [3,84]. Indeed, overexpression of MET with worsening prognosis has been reported in patients with CC RCC. In addition, a significant body of evidence has revealed that activation of MET in RCC cells promotes proliferation, invasive activity, motility, antiapoptotic activity, and angiogenesis $[3,42,84-88]$. In addition, CD105+/CD24- cancer stem cells of RCC also expressed MET, and inhibition reduced development of bone metastasis [89]. 
Phase III METEOR(NCT01865747) trial revealed that cavozantinib, a novel TK inhibitor of VEGF receptor and MET, has demonstrated favorable efficacy for progression-free survival (PFS), overall survival (OS), and objective response rate (ORR) in patients with metastatic RCC in a second- or third-line treatment setting [90]. In addition, subgroup analysis of the METEOR trial demonstrated that treatment has clinical benefits in PFS, OS, and ORR for RCC patients with bone metastases associated with poor prognosis [91].

\subsubsection{HAIs and TTSPs in RCC}

Increased expression of matriptase and hepsin was reported to be correlated with poor prognosis [3,42,92]. In addition, decreased expression of HAI-1 and HAI-2 also revealed worse prognosis in patients with RCC $[3,42,45,93]$. As mentioned above, hypermethylation of SPINT2 gene in RCC has been reported [45]. Morris et al. reported that SPINT2 promoter methylation was observed in approximately $30 \%$ of ccRCC and $40 \%$ of pRCC patients with sporadic type, and they concluded that epigenetic inactivation caused loss of tumor suppressor activities in RCC [45].

\subsubsection{MET and Matriptase/HAI-2 in Bone Metastasis}

Approximately $30 \%$ of advanced RCC patients have bone metastasis [91,94]. Osteolytic metastasis affects patient quality of life through skeletal-related events. As mentioned above, bone metastasis is reported to be a negative prognostic factor and shows resistance to multimodal treatment, including surgery, radiation, and recent VEGFR-targeted medicines [91,94]. Interestingly, immunohistochemical analysis has revealed a significant increase in the expression of MET and matriptase in bone metastasis compared with primary site [87]. In analysis of mouse model of bone metastasis using human RCC cell line (786-O), expression of HGF, matriptase and decreased expression of HAI-2 were observed in bone metastasis compared with control [88]. Furthermore, increased phosphorylation of MET was also observed in bone metastasis [88]. These reports suggested that the HGF-dependent MET signaling axis plays a significant role in RCC bone metastasis.

The evidences of Sections 3.2.1-3.2.3 are summarized in Figure 5.

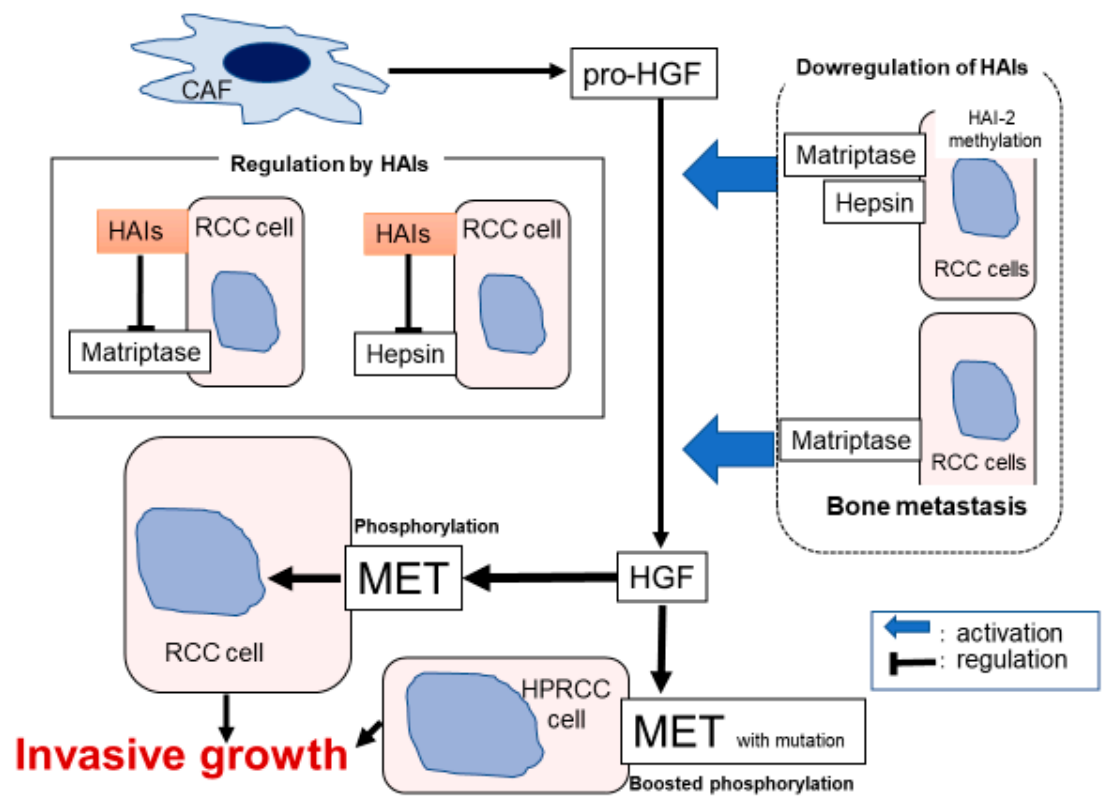

Figure 5. Hypothetical model of pericellular activation of pro-HGF in renal cell carcinoma (RCC) is shown. Downregulation of HAIs including HAI-2 methylation induced overactivation of matriptase and hepsin. In bone metastasis, increased expression of matriptase and downregulation of HAI-2 leads to the upregulation of HGF activation. In addition, phosphorylation of MET with auto-activating mutation was enhanced by HGF stimulation. 


\subsection{Bladder Cancer}

\subsubsection{Significance of HGF-dependent MET Activation in Muscle Invasive Bladder Cancer}

Pathological analysis shows that approximately $90 \%$ of bladder cancers are UC and that $5 \%$ are squamous cell carcinoma [95]. Several studies reported a positive correlation between increased expression of MET and high tumor grade, pathological staging, and survival [96-100]. Phosphorylation was also analyzed by immunohistochemistry [97,98]. Increased phosphorylation of Tyr1234/1235 (at activation loop) and Tyr1349 (at multi-docking site) was positively correlated with pT stage, and multivariate analysis prompted the authors to conclude that phosphorylated Tyr1349 was a significant predictive factor of pT stage only. In addition, phosphorylated Tyr1349 was correlated with expression of matrix metalloprotease (MMP)-2, MMP-7, and E-cadherin [97]. Furthermore, the relationship between increased phosphorylation of Tyr 1235 in MET and worse cancer-specific survival in patients with muscle invasive bladder cancer (MIBC) was reported by Yamasaki et al. In this study, increased expression of matriptase and decreased expression of HAI-1 were also correlated with poor prognosis [98]. Interestingly, the area of HAI expression and MET phosphorylation presented reciprocally in spite of the strong expression of both total MET and matriptase (Figure 6b) [98]. These findings suggested that HAI-1 may regulate the ligand-dependent activation of MET in patients with MIBC. As a biomarker, the utility of urinary soluble MET concentration to detect bladder cancer and MIBC was reported [101,102]. In vitro analysis, efficient suppression of invasion and proliferation by cabozantinib (dual inhibitor of MET and VEGFR) was observed in invasive UC cell lines (5637, T24) [103]. HGF/MET signaling-induced expression of MMP-1 was also suppressed by cabozantinib in the same cell lines. HGF/MET signaling-induced EMT is a major phenomenon in various cancer cells [103]. Recently, it has been reported that HGF/MET signaling-induced inhibition of SMURF2 yielded stabilization of TGF- $\beta$ receptor, and that upregulation of TGF- $\beta$ signaling axis leads to EMT of UC cell line [104]. However, compared with PC and RCC, the function of TTSPs and HAIs in UC is not well known. Therefore, further analysis is required.

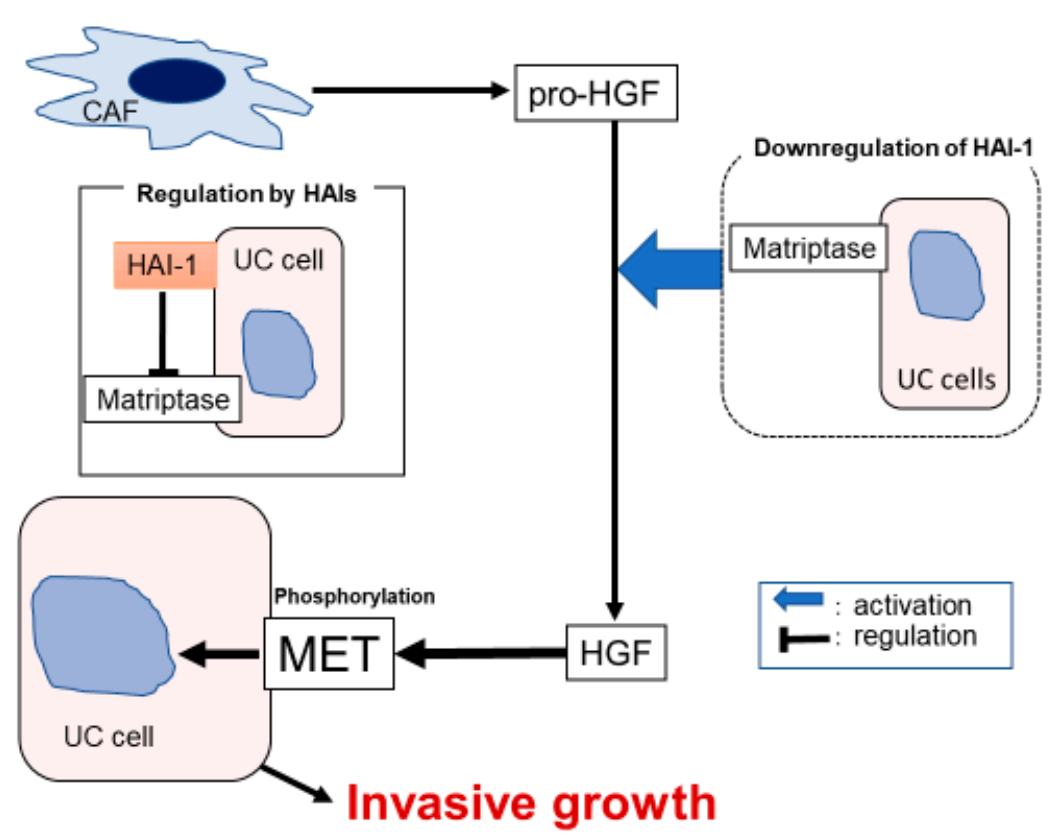

(a)

Figure 6. Cont. 

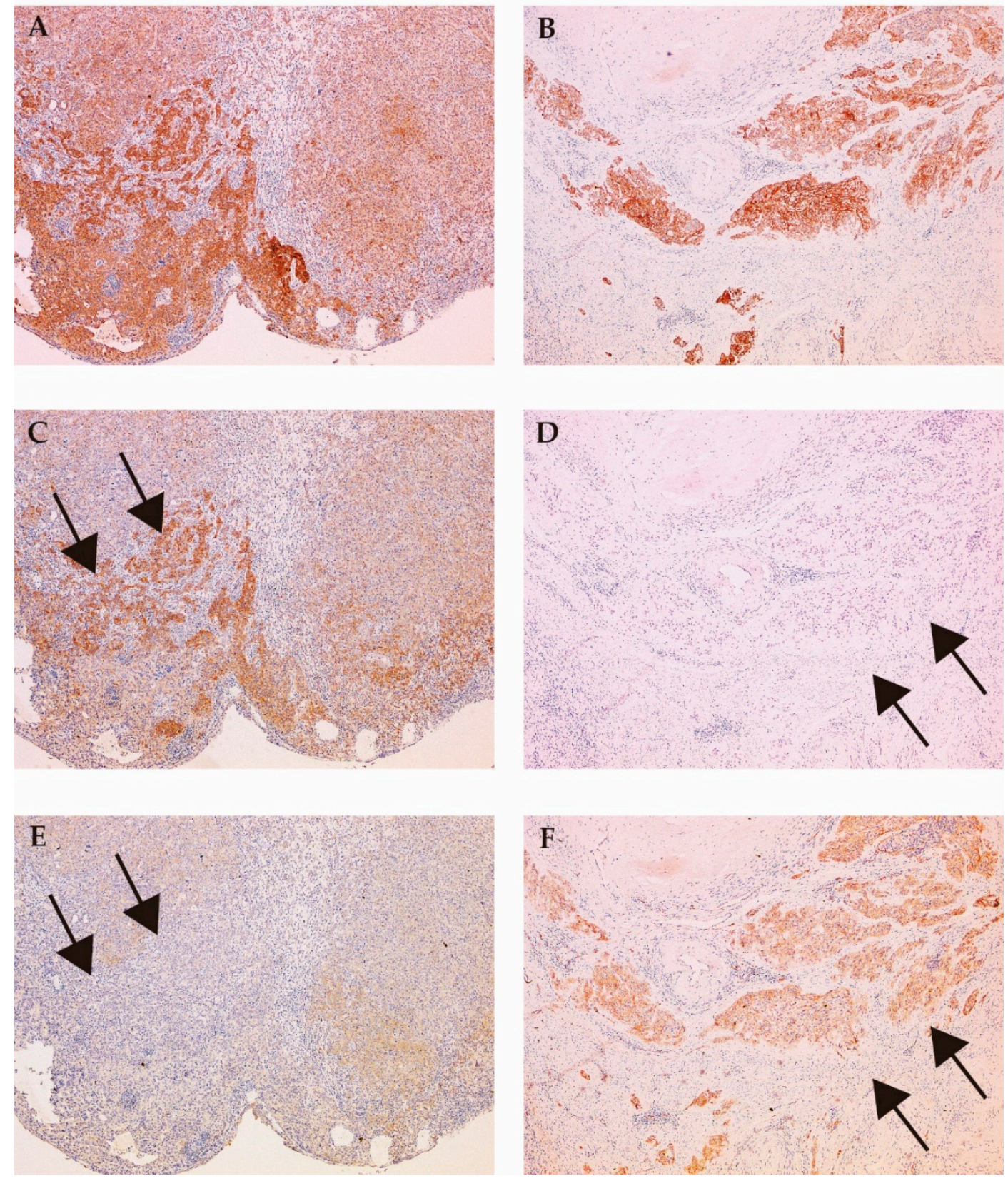

(b)

Figure 6. Hypothetical model of pericellular activation of pro-HGF in bladder urothelial carcinoma (UC) (a) is shown. Downregulation of HAI-1 induced overactivation of matriptase, which leads to upregulation of HGF-dependent MET phosphorylation (a). Immunohistochemical appearances are shown (b). Expression of MET (A-B), phosphorylated MET (C-D) and HAI-1 (E-F) is analyzed (case 1: A, C, and E; case 2: B, D, and F). Expression of MET is observed in both case 1 and case 2 (A and B). Whereas, increased phosphorylation of MET is observed in areas where expression of HAI-1 is decreased ( $\mathrm{C}$ and $\mathrm{E}$, arrows). On the other hand, phosphorylation is downregulated in areas where HAI-1 expressed ( $\mathrm{D}$ and F, allows). The results suggested regulation of MET phosphorylation by HAI-1 may have a significant role in UC.

The evidence of Section 3.3.1 is summerized in Figure 6a. 


\section{Conclusions}

In this review, we summarized the significance of pericellular pro-HGF activation in PC, RCC, and bladder cancer. Overactivation (induced by increased HGF-activating TTSPs or decreased HAIs) revealed cancer progression through MET phosphorylation.

Amplification of $M E T$ in lung cancer is a well-known mechanism of resistance to epidermal growth factor receptor-targeted tyrosine kinase inhibitors (EGFR-TKIs) [105-107]. In addition, overexpression of HGF is observed in approximately $61 \%$ of patients with EGFR-TKIs-resistant lung cancer and is known as a cause of acquired resistance $[106,107]$. The MET-signaling pathway is a major target in these patients. However, resistance to anti-MET therapy is also promoted by high amounts of pericellular HGF $[106,107]$. Therefore, the pro-HGF- activation system is significant in cancer progression. In urological cancers, several small molecule inhibitors targeting MET have been used in PC and RCC in clinical trials, and cavozantinib is used as a major agent targeting MET and VEGFR in patients with advanced RCC $[90,91,108,109]$. In addition, the efficacy of several agents for HGF and the activating TTSPs, including anti-HGF antibody, antibodies and small molecule inhibitors of hepsin and matriptase, has been reported [3,40,110-113]. Unfortunately, however, no such specific inhibitors have been verified in clinical trials $[3,10]$. Both matriptase and hepsin have other independent functions besides HGF-activation [114]. Therefore, inhibition of these TTSPs may yield additional therapeutic benefits in cancer treatment. As a candidate, the inhibitor domain of HAIs (KD1) shows significant inhibition for matriptase, hepsin, and HGFA [3,11,12,69]. Therefore, we believe KD1 has favorable therapeutic potential in urological cancers.

Author Contributions: The authors contributed in the following ways: S.M., conception of this review, reference selection and interpretation, and manuscript writing; K.Y., M.F., and T.N., review of literatures; H.K., conception of this review, review of literatures; N.T. and T.K., review of literatures and financial support. All authors have read and agreed to the published version of the manuscript.

Funding: This research received no external funding.

Acknowledgments: The authors would like to thank Ms. Junko Kurogi of Oncopathology and Regenerative Biology Section, Faculty of Medicine, University of Miyazaki for technical support of immunohistochemistry.

Conflicts of Interest: The authors declare no conflict of interest.

$\begin{array}{ll}\text { Abbreviations } \\ \text { HGF } & \text { hepatocyte growth factor } \\ \text { HGFA } & \text { hepatocyte growth factor activator } \\ \text { HAI } & \text { hepatocyte growth factor activator inhibitor } \\ \text { PC } & \text { prostate cancer } \\ \text { RCC } & \text { renal cell carcinoma } \\ \text { EMT } & \text { epithelial-mesenchymal transition } \\ \text { TTSP } & \text { type II transmembrane serine protease } \\ \text { TMPRSS } & \text { transmembrane protease, serine } \\ \text { PRCC } & \text { papillary renal cell carcinoma } \\ \text { PDGF } & \text { platelet-derived growth factor } \\ \text { PAR } & \text { protease activated receptor } \\ \text { ENaC } & \text { epithelial sodium channel } \\ \text { RNA } & \text { ribonucleic acid } \\ \text { KD } & \text { Kunitz-type serine protease inhibitor domain } \\ \text { EPCAM } & \text { epithelial cell adhesion molecules } \\ \text { PIN } & \text { prostatic intraepithelial neoplasia } \\ \text { AR } & \text { androgen receptor } \\ \text { CRPC } & \text { castration resistant prostate cancer } \\ \text { TK } & \text { tyrosine kinase } \\ \text { VHL } & \text { von Hippel-Lindau } \\ \text { MMP } & \text { matrix metalloprotease } \\ \text { UC } & \text { urothelial carcinoma } \\ \text { SMURF } & \text { SMAD specific E3 ubiquitin protein ligase 2 } \\ \text { TGF } & \text { transforming growth factor } \\ \end{array}$




\section{References}

1. Turk, B.; Turk, D.; Turk, V. Protease signalling: the cutting edge. EMBO J. 2012, 4, 1630-1643. [CrossRef] [PubMed]

2. Kataoka, H.; Tanaka, H.; Nagaike, K.; Uchiyama, S.; Itoh, H. Role of cancer cell-stroma interaction in invasive growth of cancer cells. Hum. Cell. 2003, 16, 1-14. [CrossRef] [PubMed]

3. Janetka, W.J.; Benson, M.R. Extracellular Targeting of Cell Signaling in Cancer; Strategies Directed at MET and RON Receptor Tyrosine Kinase Pathways; Wiley: Hoboken, NJ, USA, 2018; pp. 1-154.

4. Kataoka, H.; Miyata, S.; Uchinokura, S.; Itoh, H. Roles of hepatocyte growth factor (HGF) activator and HGF activator inhibitor in the pericellular activation of HGF/scatter factor. Cancer Metastasis Rev. 2003, 22, 223-236. [CrossRef]

5. Miyazawa, K.; Shimomura, T.; Kitamura, N. Activation of hepatocyte growth factor in the injured tissues is mediated by hepatocyte growth factor activator. J. Biol. Chem. 1996, 16, 3615-3618. [CrossRef] [PubMed]

6. Shimomura, T.; Kondo, J.; Ochiai, M.; Naka, D.; Miyazawa, K.; Morimoto, Y.; Kitamura, N. Activation of the zymogen of hepatocyte growth factor activator by thrombin. J. Biol. Chem. 1993, 25, 22927-22932.

7. Kataoka, H.; Kawaguchi, M. Hepatocyte growth factor activator (HGFA): pathophysiological functions in vivo. FEBS J. 2010, 277, 2230-2237. [CrossRef]

8. Kirchhofer, D.; Peek, M.; Lipari, M.T.; Billeci, K.; Fan, B.; Moran, P. Hepsin activates pro-hepatocyte growth factor and is inhibited by hepatocyte growth factor activator inhibitor-1B (HAI-1B) and HAI-2. FEBS Lett. 2005, 28, 1945-1950. [CrossRef]

9. Owen, K.A.; Qiu, D.; Alves, J.; Schumacher, A.M.; Kilpatrick, L.M.; Li, J.; Harris, J.L.; Ellis, V. Pericellular activation of hepatocyte growth factor by the transmembrane serine proteases matriptase and hepsin, but not by the membrane-associated protease uPA. Biochem. J. 2010, 426, 219-228. [CrossRef]

10. Martin, C.E.; List, K. Cell surface-anchored serine proteases in cancer progression and metastasis. Cancer Metastasis Rev. 2019, 38, 357-387. [CrossRef]

11. Kawaguchi, M.; Kataoka, H. Mechanisms of hepatocyte growth factor activation in cancer tissues. Cancers (Basel) 2014, 29, 1890-1904. [CrossRef]

12. Kataoka, H.; Kawaguchi, M.; Fukushima, T.; Shimomura, T. Hepatocyte growth factor activator inhibitors (HAI-1 and HAI-2): Emerging key players in epithelial integrity and cancer. Pathol. Int. 2018, 68, 145-158. [CrossRef] [PubMed]

13. Gentile, A.; Trusolino, L.; Comoglio, P.M. The Met tyrosine kinase receptor in development and cancer. Cancer Metastasis Rev. 2008, 27, 85-94. [CrossRef] [PubMed]

14. Trusolino, L.; Bertotti, A.; Comoglio, P.M. MET signalling: Principles and functions in development, organ regeneration and cancer. Nat. Rev. Mol. Cell Biol. 2010, 11, 834-848. [CrossRef] [PubMed]

15. Ma, P.C.; Maulik, G.; Christensen, J.; Salgia, R. c-Met: structure, functions and potential for therapeutic inhibition. Cancer Metastasis Rev. 2003, 22, 309-325. [CrossRef] [PubMed]

16. Tovar, E.A.; Graveel, C.R. MET in human cancer: germline and somatic mutations. Ann. Transl. Med. 2017, 5, 205. [CrossRef]

17. Tanabe, L.M.; List, K. The role of type II transmembrane serine protease-mediated signaling in cancer. FEBS J. 2017, 284, 1421-1436. [CrossRef]

18. List, K.; Bugge, T.H.; Szabo, R. Matriptase: potent proteolysis on the cell surface. Mol. Med. 2006, 12, 1-7. [CrossRef]

19. Wu, C.J.; Feng, X.; Lu, M.; Morimura, S.; Udey, M.C. Matriptase-mediated cleavage of EpCAM destabilizes claudins and dysregulates intestinal epithelial homeostasis. J. Clin. Investig. 2017, 127, 623-634. [CrossRef]

20. Szabo, R.; Bugge, T.H. Membrane-anchored serine proteases in vertebrate cell and developmental biology. Annu. Rev. Cell Dev. Biol. 2011, 27, 213-235. [CrossRef]

21. Rawlings, N.D.; Barrett, A.J.; Thomas, P.D.; Huang, X.; Bateman, A.; Finn, R.D. The MEROPS database of proteolytic enzymes, their substrates and inhibitors in 2017 and a comparison with peptidases in the PANTHER database. Nucleic Acids Res. 2018, 46, D624-D632. [CrossRef]

22. Cheng, M.F.; Huang, M.S.; Lin, C.S.; Lin, L.H.; Lee, H.S.; Jiang, J.C.; Hsia, K.T. Expression of matriptase correlates with tumour progression and clinical prognosis in oral squamous cell carcinoma. Histopathology 2014, 65, 24-34. [PubMed] 
23. Tsuji, A.; Torres-Rosado, A.; Arai, T.; Le Beau, M.M.; Lemons, R.S.; Chou, S.H.; Kurachi, K. Hepsin, a cell membrane-associated protease. Characterization, tissue distribution, and gene localization. J. Biol. Chem. 1991, 5, 16948-16953.

24. Tripathi, M.; Nandana, S.; Yamashita, H.; Ganesan, R.; Kirchhofer, D.; Quaranta, V. Laminin-332 is a substrate for hepsin, a protease associated with prostate cancer progression. J. Biol. Chem. 2008, 7, 30576-30584.

25. Shimomura, T.; Denda, K.; Kitamura, A.; Kawaguchi, T.; Kito, M.; Kondo, J.; Kagaya, S.; Qin, L.; Takata, H.; Miyazawa, K.; et al. Hepatocyte growth factor activator inhibitor, a novel Kunitz-type serine protease inhibitor. J. Biol. Chem. 1997, 272, 6370-6376.

26. Kawaguchi, T.; Qin, L.; Shimomura, T.; Kondo, J.; Matsumoto, K.; Denda, K.; Kitamura, N. Purification and cloning of hepatocyte growth factor activator inhibitor type 2, a Kunitz-type serine protease inhibitor. J. Biol. Chem. 1997, 272, 27558-27564. [PubMed]

27. Marlor, C.W.; Delaria, K.A.; Davis, G.; Muller, D.K.; Greve, J.M.; Tamburini, P.P. Identification and cloning of human placental bikunin, a novel serine protease inhibitor containing two Kunitz domains. J. Biol. Chem. 1997, 272, 12202-12208.

28. Kataoka, H.; Itoh, H.; Nuki, Y.; Hamasuna, R.; Naganuma, S.; Kitamura, N.; Shimomura, T. Mouse hepatocyte growth factor (HGF) activator inhibitor type 2 lacking the first Kunitz domain potently inhibits the HGF activator. Biochem. Biophy. Res. Commun. 2002, 290, 1096-1100.

29. Kataoka, H.; Shimomura, T.; Kawaguchi, T.; Hamasuna, R.; Itoh, H.; Kitamura, N.; Miyazawa, K.; Koono, M. Hepatocyte growth factor activator inhibitor type 1 is a specific cell surface binding protein of hepatocyte growth factor activator (HGFA) and regulates HGFA activity in the pericellular microenvironment. J. Biol. Chem. 2000, 275, 40453-40462.

30. Kawaguchi, M.; Takeda, N.; Hoshiko, S.; Yorita, K.; Baba, T.; Sawaguchi, A.; Nezu, Y.; Yoshikawa, T.; Fukushima, T.; Kataoka, H. Membrane-bound serine protease inhibitor HAI-1 is required for maintenance of intestinal epithelial integrity. Am. J. Pathol. 2011, 179, 1815-1826.

31. Tanaka, H.; Nagaike, K.; Takeda, N.; Itoh, H.; Kohama, K.; Fukushima, T.; Miyata, S.; Uchiyama, S.; Uchinokura, S.; Shimomura, T.; et al. Hepatocyte growth factor activator inhibitor type 1 (HAI-1) is required for branching morphogenesis in the chorioallantoic placenta. Mol. Cell Biol. 2005, 25, 5687-5698.

32. Hoshiko, S.; Kawaguchi, M.; Fukushima, T.; Haruyama, Y.; Yorita, K.; Tanaka, H.; Seiki, M.; Inatsu, H.; Kitamura, K.; Kataoka, H. Hepatocyte growth factor activator inhibitor type 1 is a suppressor of intestinal tumorigenesis. Cancer Res. 2013, 73, 2659-2670. [CrossRef] [PubMed]

33. Baba, T.; Kawaguchi, M.; Fukushima, T.; Sato, Y.; Orikawa, H.; Yorita, K.; Tanaka, H.; Lin, C.Y.; Sakoda, S.; Kataoka, H. Loss of membrane-bound serine protease inhibitor HAI-1 induces oral squamous cell carcinoma cells' invasiveness. J. Pathol. 2012, 228, 181-192. [PubMed]

34. Ning, T.; Zhang, H.; Wang, X.; Li, S.; Zhang, L.; Deng, T.; Zhou, L.; Wang, X.; Liu, R.; Bai, M.; et al. miR-221 and miR-222 synergistically regulate hepatocyte growth factor activator inhibitor type 1 to promote cell proliferation and migration in gastric cancer. Tumour. Biol. 2017, 39, 1010428317701636. [CrossRef] [PubMed]

35. Ye, J.; Kawaguchi, M.; Haruyama, Y.; Kanemaru, A.; Fukushima, T.; Yamamoto, K.; Lin, C.Y.; Kataoka, H. Loss of hepatocyte growth factor activator inhibitor type 1 participates in metastatic spreading of human pancreatic cancer cells in a mouse orthotopic transplantation model. Cancer Sci. 2014, 105, 44-51. [CrossRef] [PubMed]

36. Oberst, M.D.; Johnson, M.D.; Dickson, R.B.; Lin, C.Y.; Singh, B.; Stewart, M.; Williams, A.; al-Nafussi, A.; Smyth, J.F.; Gabra, H.; et al. Expression of the serine protease matriptase and its inhibitor HAI-1 in epithelial ovarian cancer: Correlation with clinical outcome and tumor clinicopathological parameters. Clin. Cancer Res. 2002, 8, 1101-1107. [PubMed]

37. Nakamura, K.; Abarzua, F.; Hongo, A.; Kodama, J.; Nasu, Y.; Kumon, H.; Hiramatsu, Y. The role of hepatocyte growth factor activator inhibitor-1 (HAI-1) as a prognostic indicator in cervical cancer. Int. J. Oncol. 2009, 35, 239-248. [CrossRef]

38. Nakamura, K.; Hongo, A.; Kodama, J.; Hiramatsu, Y. The role of hepatocyte growth factor activator inhibitor (HAI)-1 and HAI-2 in endometrial cancer. Int. J. Cancer 2011, 128, 2613-2624.

39. Hamasuna, R.; Kataoka, H.; Meng, J.Y.; Itoh, H.; Moriyama, T.; Wakisaka, S.; Koono, M. Reduced expression of hepatocyte growth factor activator inhibitor type-2/placental bikunin (HAI-2/PB) in human glioblastomas: Implication for anti-invasive role of HAI-2/PB in glioblastoma cells. Int. J. Cancer 2001, 93, 339-345. [CrossRef] 
40. Li, W.; Wang, B.E.; Moran, P.; Lipari, T.; Ganesan, R.; Corpuz, R.; Ludlam, M.J.; Gogineni, A.; Koeppen, H.; Bunting, S.; et al. Pegylated Kunitz domain inhibitor suppresses hepsin-mediated invasive tumor growth and metastasis. Cancer Res. 2009, 69, 8395-8402. [CrossRef]

41. Fukushima, T.; Kawaguchi, M.; Yamasaki, M.; Tanaka, H.; Yorita, K.; Kataoka, H. Hepatocyte growth factor activator inhibitor type 1 suppresses metastatic pulmonary colonization of pancreatic carcinoma cells. Cancer Sci. 2011, 102, 407-413. [CrossRef]

42. Betsunoh, H.; Mukai, S.; Akiyama, Y.; Fukushima, T.; Minamiguchi, N.; Hasui, Y.; Osada, Y.; Kataoka, H. Clinical relevance of hepsin and hepatocyte growth factor activator inhibitor type 2 expression in renal cell carcinoma. Cancer Sci. 2007, 98, 491-498. [CrossRef] [PubMed]

43. Cheng, H.; Fukushima, T.; Takahashi, N.; Tanaka, H.; Kataoka, H. Hepatocyte growth factor activator inhibitor type 1 regulates epithelial to mesenchymal transition through membrane-bound serine proteinases. Cancer Res. 2009, 69, 1828-1835. [CrossRef] [PubMed]

44. Kawaguchi, M.; Yamamoto, K.; Takeda, N.; Fukushima, T.; Yamashita, F.; Sato, K.; Kitamura, K.; Hippo, Y.; Janetka, J.W.; Kataoka, H. Hepatocyte growth factor activator inhibitor-2 stabilizes Epcam and maintains epithelial organization in the mouse intestine. Commun. Biol. 2019, 2, 11. [CrossRef] [PubMed]

45. Morris, M.R.; Gentle, D.; Abdulrahman, M.; Maina, E.N.; Gupta, K.; Banks, R.E.; Wiesener, M.S.; Kishida, T.; Yao, M.; The, B.; et al. Tumor suppressor activity and epigenetic inactivation of hepatocyte growth factor activator inhibitor type 2/SPINT2 in papillary and clear cell renal cell carcinoma. Cancer Res. 2005, 65, 4598-4606. [CrossRef]

46. Hwang, S.; Kim, H.E.; Min, M.; Raghunathan, R.; Panova, I.P.; Munshi, R.; Ryu, B. Epigenetic silencing of SPINT2 promotes cancer cell motility via HGF-MET pathway activation in Melanoma. J. Investig. Dermatol. 2015, 135, 2283-2291. [CrossRef]

47. Yue, D.; Fan, Q.; Chen, X.; Li, F.; Wang, L.; Huang, L.; Dong, W.; Chen, X.; Zhang, Z.; Liu, J.; et al. Epigenetic inactivation of SPINT2 is associated with tumor suppressive function in esophageal squamous cell carcinoma. Exp. Cell Res. 2014, 322, 149-158. [CrossRef]

48. Dong, W.; Chen, X.; Xie, J.; Sun, P.; Wu, Y. Epigenetic inactivation and tumor suppressor activity of HAI-2/SPINT2 in gastric cancer. Int. J. Cancer 2010, 127, 1526-1534. [CrossRef]

49. Tsai, C.H.; Teng, C.H.; Tu, Y.T.; Cheng, T.S.; Wu, S.R.; Ko, C.J.; Shyu, H.Y.; Lan, S.W.; Huang, H.P.; Tzeng, S.F.; et al. HAI-2 suppresses the invasive growth and metastasis of prostate cancer through regulation of matriptase. Oncogene 2014, 18, 4643-4652. [CrossRef]

50. Roversi, F.M.; Olalla Saad, S.T.; Machado-Neto, J.A. Serine peptidase inhibitor Kunitz type 2 (SPINT2) in cancer development and progression. Biomed. Pharmacother. 2018, 101, 278-286. [CrossRef]

51. Yamamoto, K.; Kawaguchi, M.; Shimomura, T.; Izumi, A.; Konari, K.; Honda, A.; Lin, C.Y.; Johnson, M.D.; Yamashita, Y.; Fukushima, T.; et al. Hepatocyte growth factor activator inhibitor-2 (HAI-2)/SPINT2 contributes to invasive growth of oral squamous cell carcinoma cells. Oncotarget 2018, 8, 11691-11706. [CrossRef]

52. Van Leenders, G.J.; Schalken, J.A. Epithelial cell differentiation in the human prostate epithelium: implications for the pathogenesis and therapy of prostate cancer. Crit. Rev. Oncol. Hematol. 2003, 46, 3-10. [CrossRef]

53. Mukai, S.; Yorita, K.; Yamasaki, K.; Nagai, T.; Kamibeppu, T.; Sugie, S.; Kida, K.; Onizuka, C.; Tsukino, H.; Kamimura, T.; et al. Expression of human kallikrein 1-related peptidase 4 (KLK4) and MET phosphorylation in prostate cancer tissue: immunohistochemical analysis. Hum. Cell. 2015, 28, 133-142. [CrossRef] [PubMed]

54. Mi, J.; Hooker, E.; Balog, S.; Zeng, H.; Johnson, D.T.; He, Y.; Yu, E.J.; Wu, H.; Le, V.; Lee, D.H.; et al. Activation of hepatocyte growth factor/MET signaling initiates oncogenic transformation and enhances tumor aggressiveness in the murine prostate. J. Biol. Chem. 2018, 28, 20123-20136. [CrossRef] [PubMed]

55. Klezovitch, O.; Chevillet, J.; Mirosevich, J.; Roberts, R.L.; Matusik, R.J.; Vasioukhin, V. Hepsin promotes prostate cancer progression and metastasis. Cancer Cell 2004, 6, 185-195. [CrossRef]

56. Nandana, S.; Ellwood-Yen, K.; Sawyers, C.; Wills, M.; Weidow, B.; Case, T.; Vasioukhin, V.; Matusik, R. Hepsin cooperates with MYC in the progression of adenocarcinoma in a prostate cancer mouse model. Prostate 2010, 1, 591-600. [CrossRef]

57. Magee, J.A.; Araki, T.; Patil, S.; Ehrig, T.; True, L.; Humphrey, P.A.; Catalona, W.J.; Watson, M.A.; Milbrandt, J. Expression profiling reveals hepsin overexpression in prostate cancer. Cancer Res. 2001, 61, 5692-5696. 
58. Tang, X.; Mahajan, S.S.; Nguyen, L.T.; Béliveau, F.; Leduc, R.; Simon, J.A.; Vasioukhin, V. Targeted inhibition of cell-surface serine protease Hepsin blocks prostate cancer bone metastasis. Oncotarget 2014, 5, 1352-1362. [CrossRef]

59. Pal, P.; Xi, H.; Kaushal, R.; Sun, G.; Jin, C.H.; Jin, L.; Suarez, B.K.; Catalona, W.J.; Deka, R. Variants in the HEPSIN gene are associated with prostate cancer in men of European origin. Hum. Genet. 2006, 120, 187-192. [CrossRef]

60. Knudsen, B.S.; Gmyrek, G.A.; Inra, J.; Scherr, D.S.; Vaughan, E.D.; Nanus, D.M.; Kattan, M.W.; Gerald, W.L.; Vande Woude, G.F. High expression of the Met receptor in prostate cancer metastasis to bone. Urology 2002, 60, 1113-1117. [CrossRef]

61. Verhoef, E.I.; Kolijn, K.; De Herdt, M.J.; van der Steen, B.; Hoogland, A.M.; Sleddens, H.F.; Looijenga, L.H.; van Leenders, G.J. MET expression during prostate cancer progression. Oncotarget 2016, 24, 31029-31036. [CrossRef]

62. Nakashiro, K.; Hara, S.; Shinohara, Y.; Oyasu, M.; Kawamata, H.; Shintani, S.; Hamakawa, H.; Oyasu, R. Phenotypic switch from paracrine to autocrine role of hepatocyte growth factor in an androgen-independent human prostatic carcinoma cell line, CWR22R. Am. J. Pathol. 2004, 165, 533-540. [CrossRef]

63. Maeda, A.; Nakashiro, K.; Hara, S.; Sasaki, T.; Miwa, Y.; Tanji, N.; Yokoyama, M.; Hamakawa, H.; Oyasu, R. Inactivation of AR activates $\mathrm{HGF} / \mathrm{c}-\mathrm{Met}$ system in human prostatic carcinoma cells. Biochem. Biophys. Res. Commun. 2006, 8, 1158-1165. [CrossRef] [PubMed]

64. Smith, M.; De Bono, J.; Sternberg, C.; Le Moulec, S.; Oudard, S.; De Giorgi, U.; Krainer, M.; Bergman, A.; Hoelzer, W.; De Wit, R.; et al. Phase III Study of Cabozantinib in Previously Treated Metastatic Castration-Resistant Prostate Cancer: COMET-1. J. Clin. Oncol. 2016, 1, 3005-3013. [CrossRef] [PubMed]

65. Qiao, Y.; Feng, F.Y.; Wang, Y.; Cao, X.; Han, S.; Wilder-Romans, K.; Navone, N.M.; Logothetis, C.; Taichman, R.S.; Keller, E.T.; et al. Mechanistic Support for Combined MET and AR Blockade in Castration-Resistant Prostate Cancer. Neoplasia 2016, 18, 1-9. [CrossRef]

66. Sanders, A.J.; Parr, C.; Davies, G.; Martin, T.A.; Lane, J.; Mason, M.D.; Jiang, W.G. Genetic reduction of matriptase- 1 expression is associated with a reduction in the aggressive phenotype of prostate cancer cells in vitro and in vivo. J. Exp. Ther. Oncol. 2006, 6, 39-48.

67. Warren, M.; Twohig, M.; Pier, T.; Eickhoff, J.; Lin, C.Y.; Jarrard, D.; Huang, W. Protein expression of matriptase and its cognate inhibitor HAI-1 in human prostate cancer: a tissue microarray and automated quantitative analysis. Appl. Immunohistochem. Mol. Morphol. 2009, 17, 23-30. [CrossRef]

68. Wu, S.R.; Teng, C.H.; Tu, Y.T.; Ko, C.J.; Cheng, T.S.; Lan, S.W.; Lin, H.Y.; Lin, H.H.; Tu, H.F.; Hsiao, P.W.; et al. The Kunitz Domain I of Hepatocyte Growth Factor Activator Inhibitor-2 Inhibits Matriptase Activity and Invasive Ability of Human Prostate Cancer Cells. Sci. Rep. 2017, 8, 15101. [CrossRef]

69. Pereira, M.S.; de Almeida, G.C.; Pinto, F.; Viana-Pereira, M.; Reis, R.M. SPINT2 deregulation in prostate carcinoma. J. Histochem. Cytochem. 2016, 64, 32-41. [CrossRef]

70. Bergum, C.; List, K. Loss of the matriptase inhibitor HAI-2 during prostate cancer progression. Prostate 2010, 15, 1422-1428. [CrossRef]

71. Wilson, S.; Greer, B.; Hooper, J.; Zijlstra, A.; Walker, B.; Quigley, J.; Hawthorne, S. The membrane-anchored serine protease, TMPRSS2, activates PAR-2 in prostate cancer cells. Biochem. J. 2005, 15 Pt 3, 967-972. [CrossRef]

72. Matsuyama, S.; Nao, N.; Shirato, K.; Kawase, M.; Saito, S.; Takayama, I.; Nagata, N.; Sekizuka, T.; Katoh, H.; Kato, F.; et al. Enhanced isolation of SARS-CoV-2 by TMPRSS2-expressing cells. Proc. Natl. Acad. Sci. USA 2020, 12. [CrossRef] [PubMed]

73. Uhlén, M.; Fagerberg, L.; Hallström, B.M.; Lindskog, C.; Oksvold, P.; Mardinoglu, A.; Sivertsson, Å.; Kampf, C.; Sjöstedt, E.; Asplund, A.; et al. The Human Protein Atlas, Tissue-based map of the human proteome. Science 2015, 347, 1260419. [CrossRef] [PubMed]

74. Shen, L.W.; Mao, H.J.; Wu, Y.L.; Tanaka, Y.; Zhang, W. TMPRSS2: A potential target for treatment of influenza virus and coronavirus infections. Biochimie 2017, 142, 1-10. [CrossRef] [PubMed] 
75. St John, J.; Powell, K.; Conley-Lacomb, M.K.; Chinni, S.R. TMPRSS2-ERG Fusion Gene Expression in Prostate Tumor Cells and Its Clinical and Biological Significance in Prostate Cancer Progression. J. Cancer Sci. Ther. 2012, 26, 94-101. [CrossRef] [PubMed]

76. Krumbholz, M.; Agaimy, A.; Stoehr, R.; Burger, M.; Wach, S.; Taubert, H.; Wullich, B.; Hartmann, A.; Metzler, M. Molecular Composition of Genomic TMPRSS2-ERG Rearrangements in Prostate Cancer. Dis. Markers. 2019, 5085373. [CrossRef]

77. Lucas, J.M.; True, L.; Hawley, S.; Matsumura, M.; Morrissey, C.; Vessella, R.; Nelson, P.S. The androgen-regulated type II serine protease TMPRSS2 is differentially expressed and mislocalized in prostate adenocarcinoma. J. Pathol. 2008, 215, 118-125. [CrossRef]

78. Lucas, J.M.; Heinlein, C.; Kim, T.; Hernandez, S.A.; Malik, M.S.; True, L.D.; Morrissey, C.; Corey, E.; Montgomery, B.; Mostaghel, E.; et al. The androgen-regulated protease TMPRSS2 activates a proteolytic cascade involving components of the tumor microenvironment and promotes prostate cancer metastasis. Cancer Discov. 2014, 4, 1310-1325. [CrossRef]

79. Ko, C.J.; Huang, C.C.; Lin, H.Y.; Juan, C.P.; Lan, S.W.; Shyu, H.Y.; Wu, S.R.; Hsiao, P.W.; Huang, H.P.; Shun, C.T.; et al. Androgen-Induced TMPRSS2 Activates Matriptase and Promotes Extracellular Matrix Degradation, Prostate Cancer Cell Invasion, Tumor Growth, and Metastasis. Cancer Res. 2015, 15, $2949-2960$. [CrossRef]

80. Chen, S.C.; Kuo, P.L. Bone metastasis from renal cell carcinoma. Int. J. Mol. Sci. 2016, 17, E987. [CrossRef]

81. Rhoades Smith, K.E.; Bilen, M.A. A Review of Papillary Renal Cell Carcinoma and MET Inhibitors. Kidney Cancer. 2019, 1, 151-161. [CrossRef]

82. Joffre, C.; Barrow, R.; Ménard, L.; Calleja, V.; Hart, I.R.; Kermorgant, S. A direct role for Met endocytosis in tumorigenesis. Nat. Cell Biol. 2011, 5, 827-837. [CrossRef] [PubMed]

83. Maher, E.R. Hereditary renal cell carcinoma syndromes: diagnosis, surveillance and management. World J. Urol. 2018, 36, 1891-1898. [CrossRef] [PubMed]

84. Harshman, L.C.; Choueiri, T.K. Targeting the hepatocyte growth factor/c-Met signaling pathway in renal cell carcinoma. Cancer J. 2013, 19, 316-323. [CrossRef] [PubMed]

85. Miyata, Y.; Kanetake, H.; Kanda, S. Presence of phosphorylated hepatocyte growth factor receptor/c-Met is associated with tumor progression and survival in patients with conventional renal cell carcinoma. Clin. Cancer Res. 2006, 15, 4876-4881. [CrossRef]

86. Nandagopal, L.; Sonpavde, G.P.; Agarwal, N. Investigational MET inhibitors to treat Renal cell carcinoma. Expert Opin. Investig. Drugs 2019, 28, 851-860. [CrossRef]

87. Mukai, S.; Yorita, K.; Kawagoe, Y.; Katayama, Y.; Nakahara, K.; Kamibeppu, T.; Sugie, S.; Tukino, H.; Kamoto, T.; Kataoka, H. Matriptase and MET are prominently expressed at the site of bone metastasis in renal cell carcinoma: immunohistochemical analysis. Hum. Cell 2015, 28, 44-50. [CrossRef]

88. Yamasaki, K.; Mukai, S.; Sugie, S.; Nagai, T.; Nakahara, K.; Kamibeppu, T.; Sakamoto, H.; Shibasaki, N.; Terada, N.; Toda, Y.; et al. Dysregulated HAI-2 Plays an Important Role in Renal Cell Carcinoma Bone Metastasis through Ligand-Dependent MET Phosphorylation. Cancers (Basel) 2018, 8, 10. [CrossRef]

89. D'Amico, L.; Belisario, D.; Migliardi, G.; Grange, C.; Bussolati, B.; D'Amelio, P.; Perera, T.; Dalmasso, E.; Dalle Carbonare, L.; Godio, L.; et al. C-met inhibition blocks bone metastasis development induced by renal cancer stem cells. Oncotarget 2016, 19, 45525-45537. [CrossRef]

90. Choueiri, T.K.; Escudier, B.; Powles, T.; Tannir, N.M.; Mainwaring, P.N.; Rini, B.I.; Hammers, H.J.; Donskov, F.; Roth, B.J.; Peltola, K.; et al. Cabozantinib versus everolimus in advanced renal cell carcinoma (meteor): Final results from a randomised, open-label, phase 3 trial. Lancet Oncol 2016, 17, 917-927. [CrossRef]

91. Escudier, B.; Powles, T.; Motzer, R.J.; Olencki, T.; Aren Frontera, O.; Oudard, S.; Rolland, F.; Tomczak, P.; Castellano, D.; Appleman, L.J.; et al. Cabozantinib, a new standard of care for patients with advanced renal cell carcinoma and bone metastases? Subgroup analysis of the meteor trial. J. Clin. Oncol. 2018, 36, 765-772. [CrossRef]

92. Roemer, A.; Schwettmann, L.; Jung, M.; Stephan, C.; Roigas, J.; Kristiansen, G.; Loening, S.A.; Lichtinghagen, R.; Jung, K. The membrane proteases adams and hepsin are differentially expressed in renal cell carcinoma. Are they potential tumor markers? J. Urol. 2004, 172 Pt 6, 2162-2166. [CrossRef]

93. Yamauchi, M.; Kataoka, H.; Itoh, H.; Seguchi, T.; Hasui, Y.; Osada, Y. Hepatocyte growth factor activator inhibitor types 1 and 2 are expressed by tubular epithelium in kidney and down-regulated in renal cell carcinoma. J. Urol. 2004, 171, 890-896. [CrossRef] [PubMed] 
94. Weber, K.; Doucet, M.; Kominsky, S. Renal cell carcinoma bone metastasis—Elucidating the molecular targets. Cancer Metastasis Rev. 2007, 26, 691-704. [CrossRef] [PubMed]

95. Abol-Enein, H.; Kava, B.R.; Carmack, A.J. Nonurothelial cancer of the bladder. Urology 2007, 69, 93-104. [CrossRef] [PubMed]

96. Parr, C.; Jiang, W.G. Expression of hepatocyte growth factor/scatter factor, its activator, inhibitors and the c-Met receptor in human cancer cells. Int. J. Oncol. 2001, 19, 857-863. [CrossRef] [PubMed]

97. Miyata, Y.; Sagara, Y.; Kanda, S.; Hayashi, T.; Kanetake, H. Phosphorylated hepatocyte growth factor receptor/c-Met is associated with tumor growth and prognosis in patients with bladder cancer: correlation with matrix metalloproteinase-2 and -7 and E-cadherin. Hum. Pathol. 2009, 40, 496-504. [CrossRef]

98. Yamasaki, K.; Mukai, S.; Nagai, T.; Nakahara, K.; Fujii, M.; Terada, N.; Ohno, A.; Sato, Y.; Toda, Y.; Kataoka, H.; et al. Matriptase-Induced Phosphorylation of MET is Significantly Associated with Poor Prognosis in Invasive Bladder Cancer; an Immunohistochemical Analysis. Int. J. Mol. Sci. 2018, 22, 19. [CrossRef]

99. Tamatani, T.; Hattori, K.; Iyer, A.; Tamatani, K.; Oyasu, R. Hepatocyte growth factor is an invasion/migration factor of rat urothelial carcinoma cells in vitro. Carcinogenesis 1999, 20, 957-962. [CrossRef]

100. Nakahara, K.; Yamasaki, K.; Nagai, T.; Fujii, M.; Akioka, T.; Takamori, H.; Terada, N.; Mukai, S.; Sato, Y.; Kamoto, T. Expression of protease activating receptor-2 (PAR-2) is positively correlated with the recurrence of non-muscle invasive bladder cancer: an immunohistochemical analysis. Res. Rep. Urol. 2019, 11, 97-104. [CrossRef]

101. McNeil, B.K.; Sorbellini, M.; Grubb, R.L., 3rd; Apolo, A.; Cecchi, F.; Athauda, G.; Cohen, B.; Giubellino, A.; Simpson, H.; Agarwal, P.K.; et al. Preliminary evaluation of urinary soluble Met as a biomarker for urothelial carcinoma of the bladder. J. Transl. Med. 2014, 21, 199. [CrossRef]

102. Matsumoto, K.; Umitsu, M.; De Silva, D.M.; Roy, A.; Bottaro, D.P. Hepatocyte growth factor/MET in cancer progression and biomarker discovery. Cancer Sci. 2017, 108, 296-307. [CrossRef] [PubMed]

103. Shintani, T.; Kusuhara, Y.; Daizumoto, K.; Dondoo, T.O.; Yamamoto, H.; Mori, H.; Fukawa, T.; Nakatsuji, H.; Fukumori, T.; Takahashi, M.; et al. The Involvement of Hepatocyte Growth Factor-MET-Matrix Metalloproteinase 1 Signaling in Bladder Cancer Invasiveness and Proliferation. Effect of the MET Inhibitor, Cabozantinib (XL184), on Bladder Cancer Cells. Urology 2017, 101, 169-169.e7. [CrossRef] [PubMed]

104. Sim, W.J.; Iyengar, P.V.; Lama, D.; Lui, S.K.L.; Ng, H.C.; Haviv-Shapira, L.; Domany, E.; Kappei, D.; Tan, T.Z.; Saei, A.; et al. c-Met activation leads to the establishment of a TGF $\beta$-receptor regulatory network in bladder cancer progression. Nat. Commun. 2019, 25, 4349. [CrossRef] [PubMed]

105. Owusu, B.Y.; Thomas, S.; Venukadasula, P.; Han, Z.; Janetka, J.W.; Galemmo, R.A., Jr.; Klampfer, L. Targeting the tumor-promoting microenvironment in MET-amplified NSCLC cells with a novel inhibitor of pro-HGF activation. Oncotarget 2017, 8, 63014-63025. [CrossRef] [PubMed]

106. Pennacchietti, S.; Cazzanti, M.; Bertotti, A.; Rideout, W.M., 3rd; Han, M.; Gyuris, J.; Perera, T.; Comoglio, P.M.; Trusolino, L.; Michieli, P. Microenvironment-derived HGF overcomes genetically determined sensitivity to anti-MET drugs. Cancer Res. 2014, 15, 6598-6609. [CrossRef]

107. Suda, K.; Mizuuchi, H.; Maehara, Y.; Mitsudomi, T. Acquired resistance mechanisms to tyrosine kinase inhibitors in lung cancer with activating epidermal growth factor receptor mutation-diversity, ductility, and destiny. Cancer Metastasis Rev. 2012, 31, 807-814. [CrossRef]

108. Lee, Y.H.; Apolo, A.B.; Agarwal, P.K.; Bottaro, D.P. Characterization of HGF/Met Signaling in Cell Lines Derived From Urothelial Carcinoma of the Bladder. Cancers (Basel) 2014, 25, 2313-2329. [CrossRef]

109. Miyata, Y.; Asai, A.; Mitsunari, K.; Matsuo, T.; Ohba, K.; Mochizuki, Y.; Sakai, H. Met in urological cancers. Cancers (Basel) 2014, 16, 2387-4203. [CrossRef]

110. Han, Z.; Harris, P.K.; Jones, D.E.; Chugani, R.; Kim, T.; Agarwal, M.; Shen, W.; Wildman, S.A.; Janetka, J.W. Inhibitors of HGFA, matriptase, and hepsin serine proteases: A nonkinase strategy to block cell signaling in Cancer. ACS Med. Chem. Lett. 2014, 5, 1219-2124. [CrossRef]

111. Franco, F.M.; Jones, D.E.; Harris, P.K.; Han, Z.; Wildman, S.A.; Jarvis, C.M.; Janetka, J.W. Structure-based discovery of small molecule hepsin and HGFA protease inhibitors: Evaluation of potency and selectivity derived from distinct binding pockets. Bioorg. Med. Chem. 2015, 23, 2328-2343. [CrossRef]

112. Han, Z.; Harris, P.K.; Karmakar, P.; Kim, T.; Owusu, B.Y.; Wildman, S.A.; Klampfer, L.; Janetka, J.W. $\alpha$-Ketobenzothiazole serine protease inhibitors of aberrant HGF/c-MET and MSP/RON kinase pathway signaling in cancer. ChemMedChem 2016, 11, 585-599. [CrossRef] [PubMed] 
113. Forbs, D.; Thiel, S.; Stella, M.C.; Sturzebecher, A.; Schweinitz, A.; Steinmetzer, T.; Stürzebecher, J.; Uhland, K. In vitro inhibition of matriptase prevents invasive growth of cell lines of prostate and colon carcinoma. Int. J. Oncol. 2005, 27, 1061-1070. [CrossRef] [PubMed]

114. Ustach, C.V.; Huang, W.; Conley-LaComb, M.K.; Lin, C.Y.; Che, M.; Abrams, J.; Kim, H.R. A novel signaling axis of matriptase/PDGF-D/ss-PDGFR in human prostate cancer. Cancer Res 2010, 70, 9631-9640. [CrossRef] [PubMed]

(C) 2020 by the authors. Licensee MDPI, Basel, Switzerland. This article is an open access article distributed under the terms and conditions of the Creative Commons Attribution (CC BY) license (http://creativecommons.org/licenses/by/4.0/). 